\title{
Three Large Historical Landslide Dams and Outburst Disasters in the North Fossa Magna Area, Central Japan
}

\author{
Kimio INOUE ${ }^{1}$, Toshio MORI ${ }^{2}$ and Takahisa MIZUYAMA ${ }^{3}$ \\ ${ }^{1}$ Sabo Frontier Foundation (Sabo-Kaikan, Hirakawa-cho 2-7-4, Chiyoda-ku, Tokyo 102-0093, Japan) \\ Email: k-inoue@sff.or.jp) \\ ${ }^{2}$ Sabo Frontier Foundation (Sabo-Kaikan, Hirakawa-cho 2-7-4, Chiyoda-ku, Tokyo 102-0093, Japan) \\ ${ }^{3}$ Division of Forest Science, Graduate School of Agriculture, Kyoto University (Kitashirakawa, Sakyo-ku, Kyoto 606-8502, Japan)
}

\begin{abstract}
Large landslides or debris flows caused by heavy rainfall or earthquakes often block rivers in mountainous areas and form landslide dams. The area upstream of the landslide dam is submerged under water and the downstream area is flooded when the landslide dam breaks. In recorded history, as many as 22 landslide dams have formed upstream of the Shinano River and the Hime River, in the northern part of Nagano Prefecture in central Japan, and all except three have subsequently broken. This abundance of landslide dams is probably caused by the geotectonic background of this area, which is located at the western end of the "Fossa Magna" major tectonic line. In this study, we examined three large historical landslide dams and outburst disasters in the north Fossa Magna area.
\end{abstract}

Keywords: Landslide Dam, Debris Avalanche, Tobata Landslide, Zenkoji Earthquake, Mt. Iwakura Landslide

\section{INTRODUCTION}

We have studied the history, formation, and outburst flood events of landslide dams and have reported our findings at several Interpraevent meetings [Mizuyama et al., 2004; Inoue 2010; Inoue et al., 2008, 2012]. We have also published two books regarding the formation and outburst flood events of landslide dams in Japan [Tabata et al., 2002; Mizuyama et al., 2011].

Major flooding damage may occur downstream if a large landslide dam bursts releasing the water behind it. A number of researchers have compiled and reported data on landslide dams [e.g., Schuster, 1986; Tabata et al., 2002; Mizuyama et al., 2011]. In recent examples from Japan, large landslide dams formed in the Imo River, a tributary of the Shinano River, as a result of the Niigata Prefecture Chuetsu (Mid-Niigata) Earthquake that occurred on 23 October, 2004 [Mizuyama et al., 2011]. Landslide dams also formed on the Kii Peninsula when typhoon No. 12 struck in September 2011 [Inoue, 2012]. Various countermeasure methods were taken to prevent the bursting of these dams.

A survey of past sediment floods and alluvial fans caused by a major collapse or other sediment yielding in the upstream area showed that many were triggered by the bursting of landslide dams.
Table 1 List of landslide dams documented in northern Nagano Prefecture (Mizuyama et al, 2011)

\begin{tabular}{|c|c|c|c|c|c|c|}
\hline No. & Landslide Dam & Date Formed & Cause & & Failure Timing & River \\
\hline 1 & Aoki Lake & 30,000 years ago & Unknown & & \begin{tabular}{|l|} 
Continuing today \\
\end{tabular} & Takase R. \\
\hline 2 & Old Chikuma & 887.8.22 & oki Shichido Earhquake & $\mathrm{O}$ & 303 days later & Chikuma R. \\
\hline 3 & Old Aiki & 888.6.20 & Secondary debris avalanche & & 600 years later & Aiki R. \\
\hline 4 & Kashima River & 1441.7 & Heavy Rain & $\square$ & 3 days later & Kashima R. \\
\hline 5 & Mt. Manaita & 1502.1.28? & Essa Earthquake & 0 & & Hime $\mathbf{R}$. \\
\hline 6 & Mt. Shimizu & 1502.1.28? & Essa Earthquake & $\mathrm{O}$ & Unknown & Nakatani R. \\
\hline 8 & Mt. Iwato & 1714.4.28 & inshu Otari Earthquake & ( & 3 days later & Hime R. \\
\hline 7 & Toba & 4 & Heavy Rain & $\square$ & $54 \mathrm{~h}$ & Azusa R. \\
\hline 9 & Mt. Iwakura & 08 & Zenkoji Earth & $\bar{O}$ & 19 days later & Sai R. \\
\hline 10 & Kiriake & 08 & Zenkoji Eart & 0 & Gradua & Nakatsu R. \\
\hline 11 & Mt. Amamizu & 5.08 & Zenkoji Earth & 0 & A few days later & Shinano R. \\
\hline 12 & Yanakubo Lake & & Zenkoji Earthquake & 0 & Continuing today & Yanakubo $\mathrm{R}$. \\
\hline 13 & Ikari & 1847.5.08 & Zenkoji Earthquake & $\mathrm{O}$ & 16 days later & Dojiri R. \\
\hline 14 & Somuro & 1847.5.08 & Zenkoji Earthquake & 0 & Gradually failed & Somuro $\mathbf{R}$. \\
\hline 15 & Oyasawa & & Zent & 0 & & Susobana R. \\
\hline 16 & Garagara Sawa & 16 & Heavy Rain & $\square$ & \begin{tabular}{|l|} 
Gradually failed \\
\end{tabular} & Matsu R. \\
\hline 17 & Mt. Hieda & & Heavy Rain & $\square$ & 3 days later & Hime $\mathrm{R}$. \\
\hline 18 & Taisho Lake & & Eruption & ( & \begin{tabular}{|l|} 
Continuing today \\
\end{tabular} & Azusa.R. \\
\hline 19 & Mt. Kazahari & 9.4 .21 & Snowmelting Flood & $\square$ & \begin{tabular}{|l|} 
Gradually failed \\
\end{tabular} & Hime $\mathrm{R}$. \\
\hline 20 & Mt. A & & towmelt & 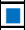 & $\overline{101 \mathrm{~d}}$ & Odokoro R. \\
\hline 21 & Mt. Kozuchi & 1971.7.16 & eavy Rain & $\square$ & \begin{tabular}{|c|} 
Gradually failed \\
\end{tabular} & Hime $R$. \\
\hline 22 & Oku Susobana & 1997.5.05 & Snowmelting Flood & & $\begin{array}{c}\text { Did not fail due to } \\
\text { countermeasures }\end{array}$ & Susobana \\
\hline
\end{tabular}

However, to date, sediment control plans have focused on collapses and landslides, ignoring the formation and bursting of landslide dams. To fully understand sediment-related disasters, we must consider the formation and bursting phenomena of landslide dams. Thus, in this study, we analyzed past landslide dams using a variety literature, sources, maps, and historical documents. These case studies can aid in predicting the potential locations and scale of landslide dams and in future sediment control planning. 


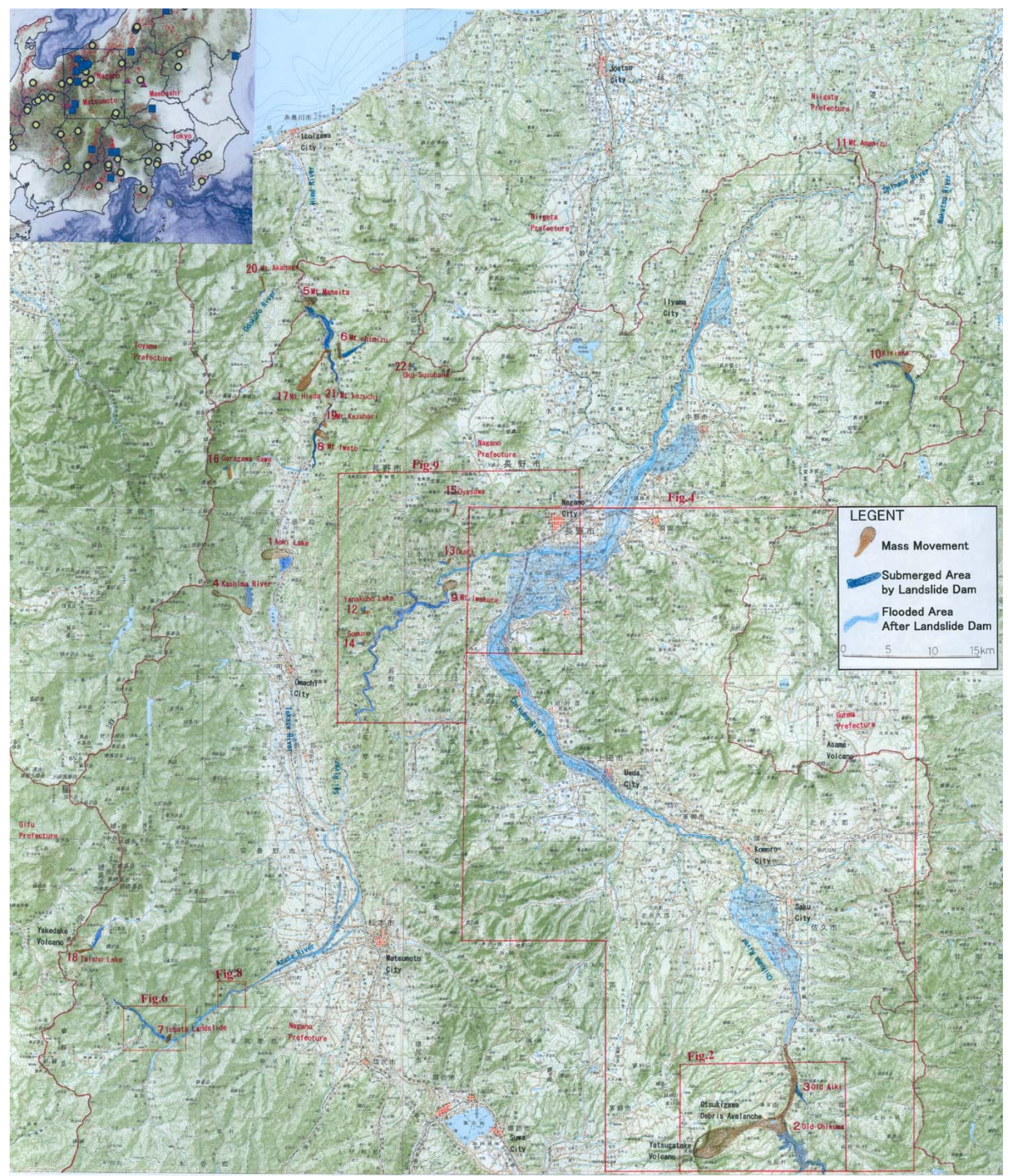

Fig. 1 Distribution of landslide dams in the northern part of Nagano Prefecture, central Japan (See Table 1 for the numbers of landslide dams)

\section{DISTRIBUTION OF LANDSLIDE DAMS IN THE NORTH FOSSA MAGNA AREA}

Table 1 lists landslide dams in the northern region of the Fossa Magna, in central Japan. As many as 22 landslide dams have been recorded in this area and all except three of these have broken.
This abundance of landslide dams is probably caused by the geotectonic background of the area, which is located at the western margin of the Fossa Magna, Japan's great central graben belt [Geological Survey of Japan, 1995]. The Shinano River, which is the longest river in Japan, runs through the mountainous region of central Japan and flows into the Sea of Japan. 


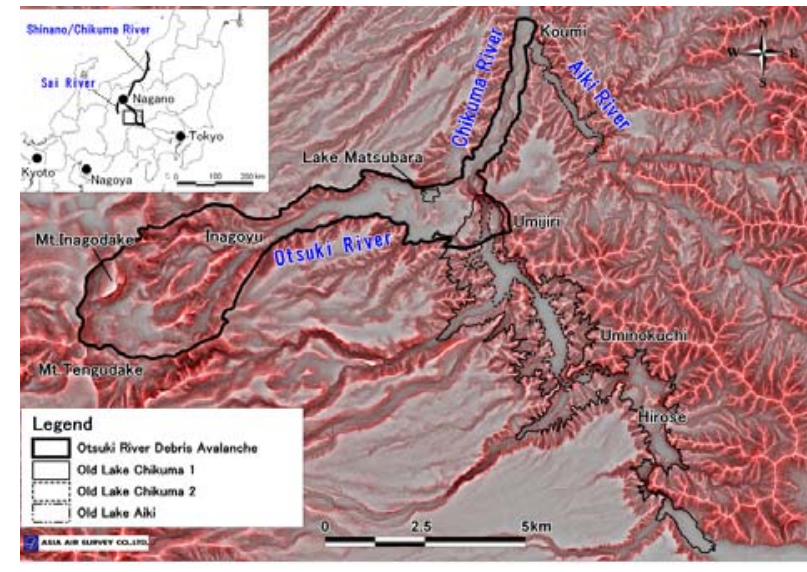

Fig.2 Relief map of Yatsugatake Volcano, the debris avalanche, and the landside dams formed (Inoue et al., 2012)

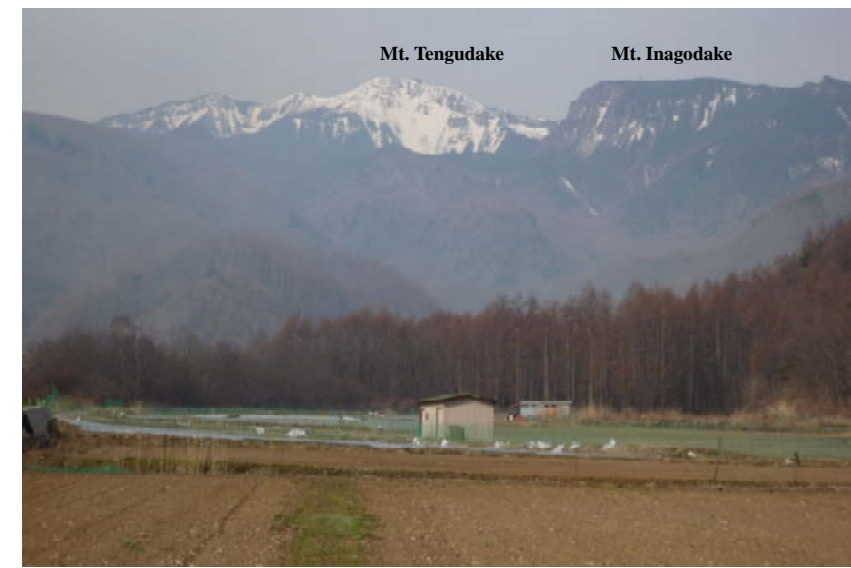

Photo 1 Terrain around the Otsuki River debris avalanche after a large-scale sector collapse in North Yatsugatake

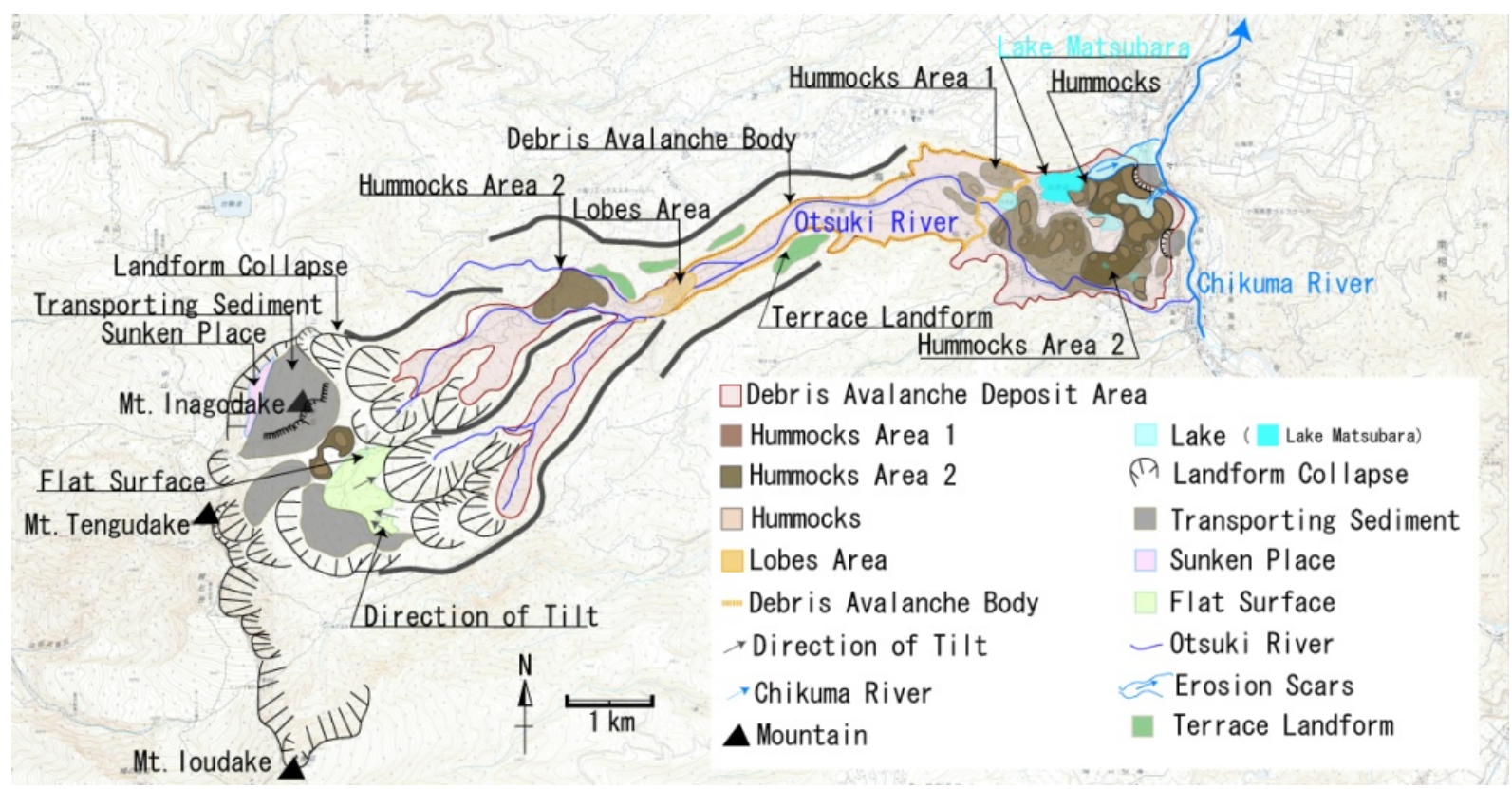

Fig. 3 Landforms of the Otsuki River basin (Machida et al., 2009; Inoue et al., 2012)

\section{LANDSLIDE DAM FORMED IN 887}

Yatsugatake Volcano in Nagano Prefecture was violently shaken by an earthquake on 22 August, 887 (30 September, Ninna Era, Japanese lunar calendar), which caused a large-scale collapse. The collapse debris flowed down the Otsuki River in the form of a large-scale debris avalanche and blocked the Chikuma River, upstream of the Shinano River, forming a gigantic landslide dam in the upper reaches. Figure 2 shows a relief map of the Yatsugatake Volcano, the debris avalanche, and the land-slide dams that formed [Inoue et al., 2010]. In the area from Sakudaira to the Nagano Basin along the Chikuma River, Ninna Flood sand covered rice paddies and houses.

This disaster is mentioned in many historical materials, including records from the 887 earthquake and from the flood disasters of 888 . These materials can be interpreted to show that on 22 August 887, in addition to the disaster caused by a violent earthquake (large ocean-trench earthquake) that affected most of the main Japanese islands, a massive collapse occurred in the Yatsugatake Volcano, which blocked the Chikuma River and resulted in the formation of a huge landslide dam. Subsequently on 20 June, 888 (303 days later), the landslide dam collapsed, causing a heavy flood that washed away both houses and castles in six districts of Nagano Prefecture and caused numerous human fatalities.

Kawachi [1983] suggested that the collapse of the eastern flank of Yatsugatake Volcano resulted in the formation of a horseshoe-shaped caldera of 2.25 $\mathrm{km}$ in north-south length, $3.5 \mathrm{~km}$ in east-west length and $350 \mathrm{~m}$ in maximum relative height and estimated that the sediment from the Otsuki River 
Table 2 Ruins covered with Ninna Flood sand (Inoue et al., 2010)

\begin{tabular}{|r|l|l|l|l|}
\hline No & Ruins Name & Addres & Latitude & Longitude \\
\hline 1 & Shinonoi Ruins Group & Nagano City Shinonoi Shiozaki & $\mathrm{N} 36^{\circ} 33^{\prime}$ & $\mathrm{E} 138^{\circ} 07^{\prime}$ \\
2 & Ishikawa Jori Ruins & Nagano City Shinonoi Shiozaki & $\mathrm{N} 36^{\circ} 33^{\prime}$ & $\mathrm{E} 138^{\circ} 06^{\prime}$ \\
3 & Shiozaki Ruins Group. & Nagano City Shinonoi Shiozaki & $\mathrm{N} 36^{\circ} 34^{\prime}$ & $\mathrm{E} 138^{\circ} 08^{\prime}$ \\
4 & Yashiro Ruins Group & Chikuma City Amenomiya & $\mathrm{N} 36^{\circ} 32^{\prime}$ & $\mathrm{E} 138^{\circ} 09^{\prime}$ \\
5 & Koshoku Ruins Group & Chikuma City Yashiro & $\mathrm{N} 36^{\circ} 31^{\prime}$ & $\mathrm{E} 138^{\circ} 09^{\prime}$ \\
\hline 6 & Chikaraishi Jori Ruins & Chikuma City Chikaraishi & $\mathrm{N} 36^{\circ} 28^{\prime}$ & $\mathrm{E} 138^{\circ} 10^{\prime}$ \\
7 & Kamigomyo Jori Ruins & Sakaki Town Kamigomyo & $\mathrm{N} 36^{\circ} 27^{\prime}$ & $\mathrm{E} 138^{\circ} 10^{\prime}$ \\
8 & Aokishita Ruins & Sakaki Town Minamijo & $\mathrm{N} 36^{\circ} 26^{\prime}$ & $\mathrm{E} 138^{\circ} 11^{\prime}$ \\
9 & Sunahara Ruins & Saku City Shionata Shinada & $\mathrm{N} 36^{\circ} 16^{\prime}$ & $\mathrm{E} 138^{\circ} 25^{\prime}$ \\
10 & Atobe Mamada Ruins & Saku City Atobe Mamada & $\mathrm{N} 36^{\circ} 14^{\prime}$ & $\mathrm{E} 138^{\circ} 28^{\prime}$ \\
\hline
\end{tabular}

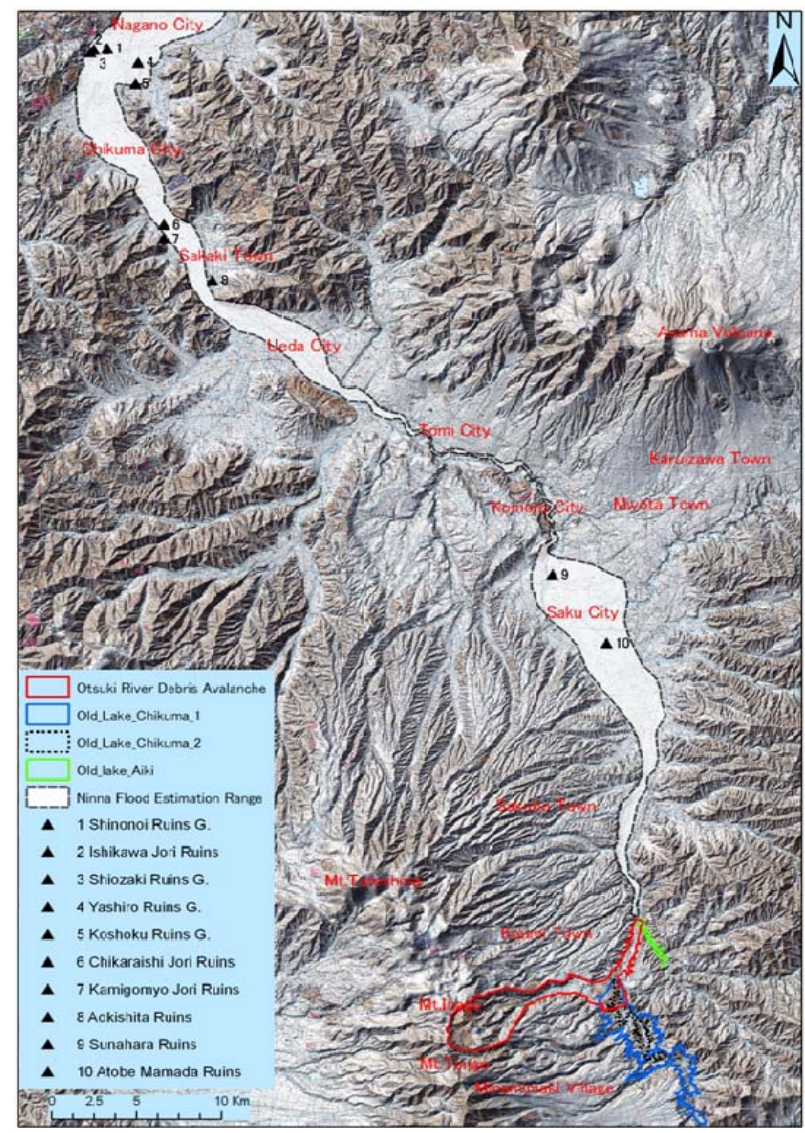

Fig. 4 Extent of the Otsuki River debris avalanche, landslide dam and flood-distribution of sites covered with Ninna Flood sand (Inoue et al., 2011)

debris avalanche amounted to 350 million $\mathrm{m}^{3}$. Photo 1 shows the terrain around the Otsuki River debris avalanche after the large-scale collapse at North Yatsugatake, Shinkai. We later estimated the volume of the horseshoe-shaped caldera as over 1 billion $\mathrm{m}^{3}$ and postulate that this landform was a result of repeated debris avalanches as large as that which occurred in 887 , along with volcanic activity such as phreatic explosions.

Interpretation of a 1/25000 topographic map and aerial photos; suggested that the altitude of the river bed at the point of the river channel blockage was $1000 \mathrm{~m}$ above sea level. Debris including avalanche sediment present along the Otsuki River and there are many mudflow hill landforms and lakes including Lake Matsubara, resulting from the debris avalanche. Figure 3 shows a landform classification map of the Otsuki River basin. Considering the existing of extrusive landforms such as mudflow hills near Lake Matsubara, the inundation height was estimated to be $130 \mathrm{~m}$. Tracing the contour line at this altitude results in an estimated inundation area and volume of approximately $13.5 \mathrm{~km}^{2}$ and 580 million $\mathrm{m}^{3}$, respectively, which would make it one of the largest landslide dams known to have occurred in Japan. This landslide dam formed along the Chikuma River and had an extremely large inundation volume, which gradually collected water for about ten months. The dam eventually became filled during torrential rainfall in the rainy season. It suddenly failed 303 days later, causing a secondary debris avalanche. The water collected behind the landslide dam flowed for over $100 \mathrm{~km}$ down the Chikuma River as massive flood waves, which resulted in flooding and the deposit of the Ninna Flood sand. Table 2 shows ruins covered with Ninna Flood sand [Inoue et al., 2010; Kawasaki, 2010].

Figure 4 shows the extent of the Otsuki River debris avalanche, the landslide dam, and the flood distribution, estimated based on the sites covered with Ninna Flood sand. Assuming the landslide dam reservoir had filled for 303 days (26.1 million seconds), the average rate of inflow from the upper reaches of the Chikuma River can be calculated as $22.2 \mathrm{~m}^{3} / \mathrm{s}$ (the catchment area upstream is $353 \mathrm{~km}^{2}$ ).

Mt. Inagodake remains at the head of the caldera as a massive moving rock body, with an approximately $1000 \mathrm{~m}$ long axis, $700 \mathrm{~m}$ short axis, $200 \mathrm{~m}$ height, and 140 million $\mathrm{m}^{3}$ in estimated volume (Photo 1 and Figure 3). This moving rock mass may have been formed at the time of the mountain body collapse in 887. Alternatively the moving rock mass may have existed earlier and the mountain body collapse may have occurred on a large scale that included part of the rock mass. This movingrock mass is almost completely separated from the bedrock and may collapse significantly in the future as a result of earthquake activity, torrential rainfall, or post-volcanic activity.

A considerable amount of literature has been published on the Yatsugatake Volcano/Otsuki River debris avalanche and the Ninna Flood, and many scenarios have been proposed for the events of 887 and 888 . The phenomena mentioned in the literature can be explained by the theory described above; namely, a large 130-m- height landslide dam (with an inundation volume of 580 million $\mathrm{m}^{3}$ ) created a reservoir that filled for as long as 303 days before bursting.

The landslide dam failure caused a secondary debris avalanche, which blocked the Aiki River 


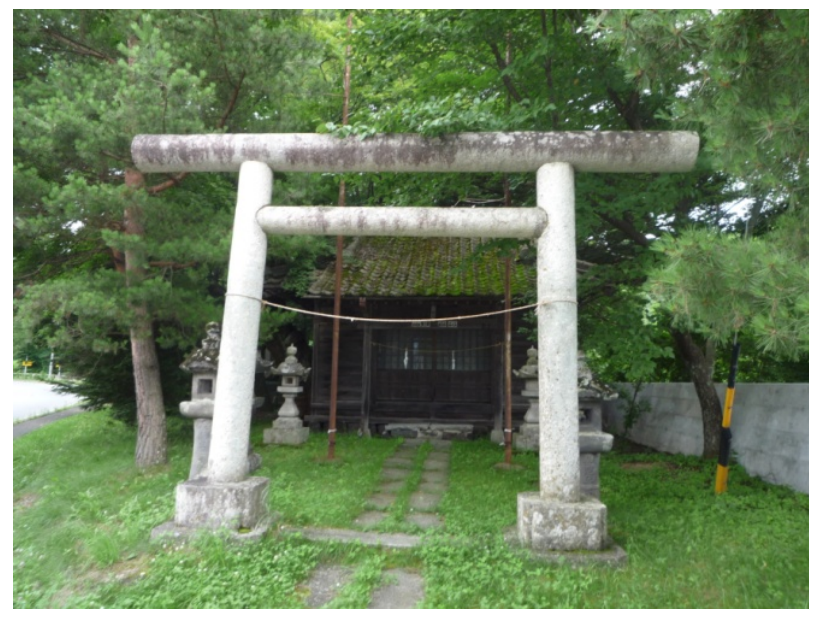

Photo 2 Minato Shrine ("Port”Shrine) (photo by Inoue)

near Koumi and formed Old Lake Aiki, which subsequently remained for over 600 years. Although Old Lake Chikuma 1 collapsed, Old Lake Chikuma 2 (50 m height) existed for 123 years.

Photo 2 shows Minato Shrine ("Port" Shrine).

Various place-names related to the lake; including Uminokuchi ("Enter the Lake"), Umijiri ("Exit the lake") and Koumi ("Small Lake") still exist in the upper reaches of the Chikuma River.

These names could be constructed as records of the landslide dam phenomena.

Figure 5 presented a map of the southern part of Saku in Kurumizawa showing Old Aiki Lake (blue circle).

\section{LANDSLIDE DAM FORMED IN 1757}

In the Azusa River, three dams -the Nagawado, Midono, and Inekoki dams- were completed in 1969 by a power generation company and have since been producing hydropower. The Nagawado Dam is an arch dam, $155 \mathrm{~m}$ high, and Lake Azusa, with a total storage capacity of 123 million $\mathrm{m}^{3}$, is its dammed lake. Figure 6 shows the location of the Nagawado Dam and the Tobata landslide in the upstream section of the Azusa River.

Photo 3 is an aerial photograph showing the Tobata landslide before the impounding of Lake Azusa. This area is composed of Mino Terrane rocks of the Jurassic Period. The local geology consists of an alternation of chert and sandstone/mudstone, striking roughly in the northeast-southwest direction [Otsuka \& Nemoto, 2003]. A few faults also run in the same direction, together with fractured zones ranging from several tens of centimeters to several meters in width.

Figure 7 shows a longitudinal section of the Azusa River in the upstream area of the Shinano River and the location of the Tobata landslide dam

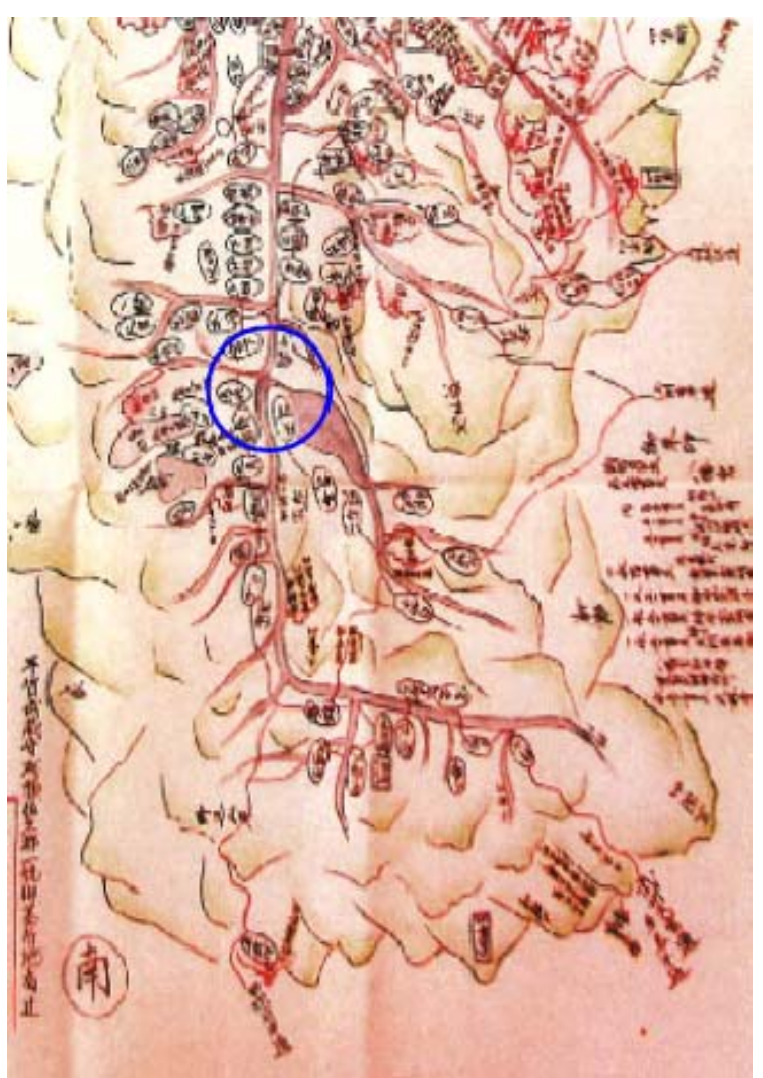

Fig. 5 Map showing the southern part of Saku in Kurumisawa Map (owned by Ryuichi Kurumisawa)

reservoir and the hydropower dam reservoirs.

In the early morning of 24 June, 1757, the Tobata landslide occurred on the left bank of the Azusa River following torrential downpours in the rainy season.

The estimated sediment movement was 10 million $\mathrm{m}^{3}$. A large landslide dam formed in the Azusa River. Analysis of historical records, old topographical maps, and an aerial photograph of the upstream reservoir in the Azusa River indicates that the water depth reached $150 \mathrm{~m}$ and the water volume reached 98 million $\mathrm{m}^{3}$. Around 10 a.m. on the third day (54 hours after the landslide), the landslide dam burst and its floodwater entered Matsumoto-Daira (an alluvial fan) up to the confluence with the Narai River, in the upstream area of the Shinano River.

Figure 7 shows the outburst flood area at $12 \mathrm{~km}$ downstream of the landslide dam. The Zousui Bridge, which was $14.4 \mathrm{~m}$ above the water level and $34.2 \mathrm{~m}$ long, was located $12 \mathrm{~km}$ downstream [Azumi Museum of Matsumoto City, 2006]. The bridge was washed away by the flood, suggesting that the water depth at peak flow was $20 \mathrm{~m}$.

According to calculations using Manning's formula, it was estimated that the flood water flowed down the river in a concentrated path with a velocity of $12 \mathrm{~m} / \mathrm{s}$ and a peak flow of $27,000 \mathrm{~m}^{3} / \mathrm{s}$. 


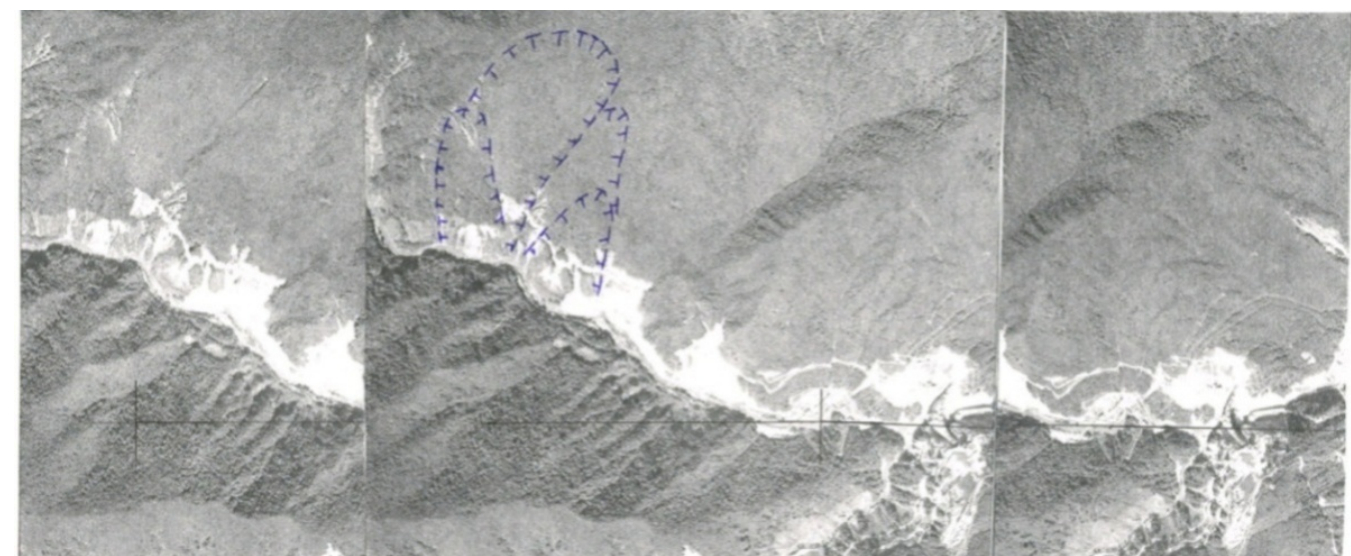

Photo 3 Tobata landslide before the impounding of Lake Azusa (Photographed on 20 Sept. 1968)

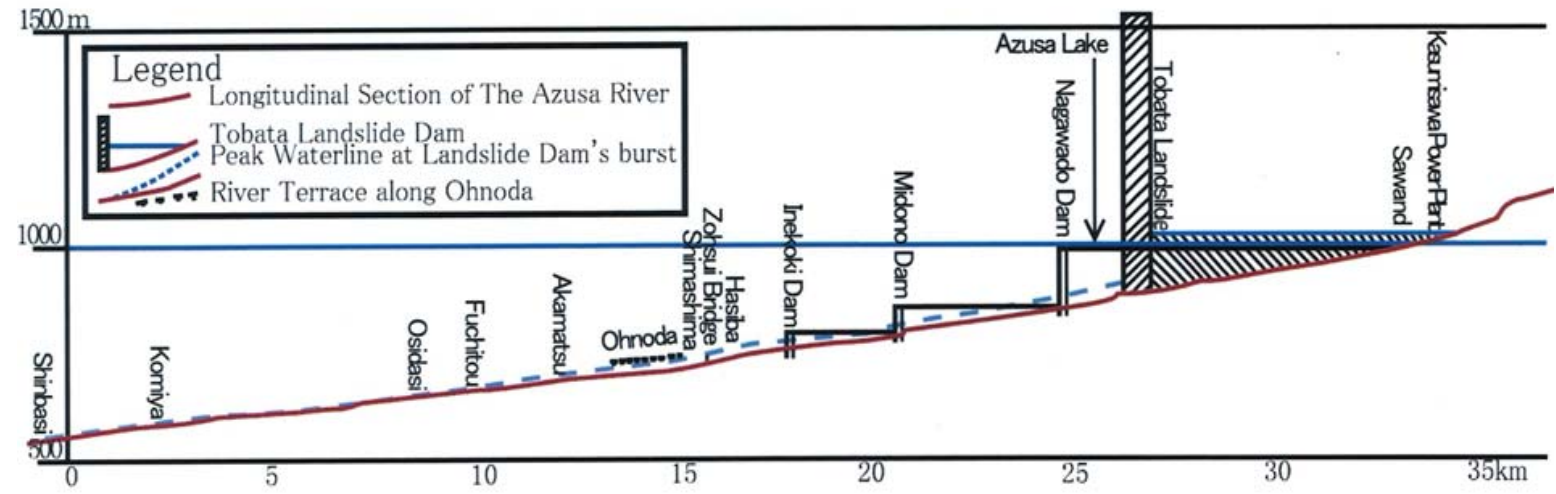

Fig. 6 Longitudinal section of Azusa River and Location of Tobata Landslide dam reservoirs and hydropower dam reservoirs (Mori et al., 2007; Inoue et al., 2008)

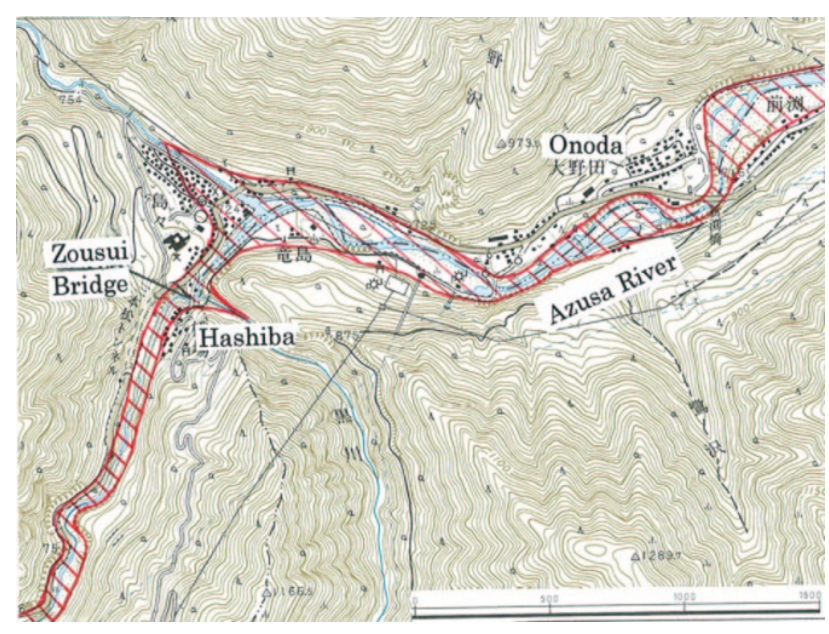

Fig.7 Estimated range of outburst flood $12 \mathrm{~km}$ downstream of the landslide dam (Mori et al., 2007)

When the dam burst, local people were quickly ordered to evacuate. The lords ruling the area (the Matsumoto feudal clans) at the time collaborated with local people to monitor and quickly evacuate the site. Although houses and arable land were washed away, there were few casualties because people were quickly evacuated to safe locations.

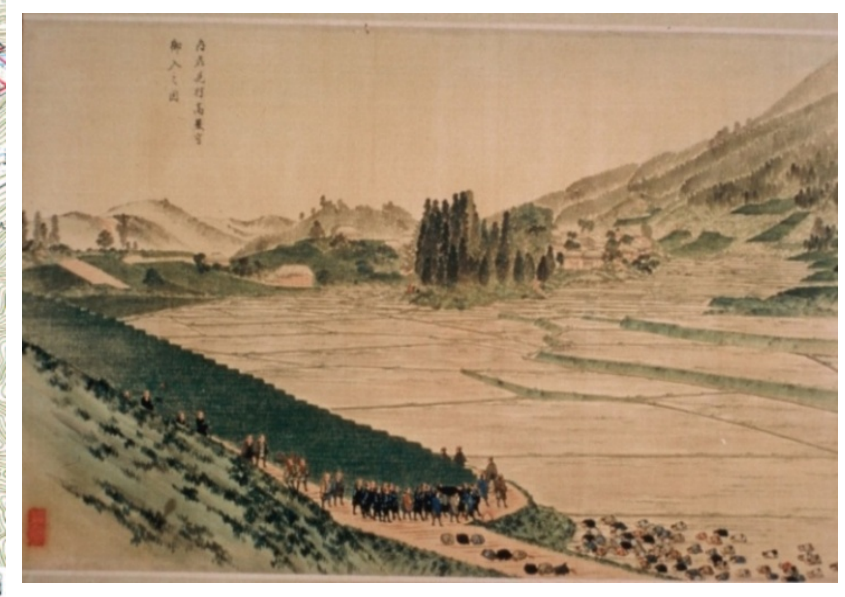

Fig.8 Yukitsura Sanada started an inspection tour of his territory sketched by Sekkei Aoki, No.10 (Sanada Musium)

\section{LANDSLIDE DAM FORMED IN 1847}

Zenkoji Earthquake occurred in 8 May, 1847 and had a magnitude of 7.4 on the Richter scale. Large landslides and collapses occurred in various locations, forming several landslide dams. This area consists of a Neogene formation that is prone to landslides and collapses. Landslide dams formed easily, similar to the case of the Niigata Prefecture 


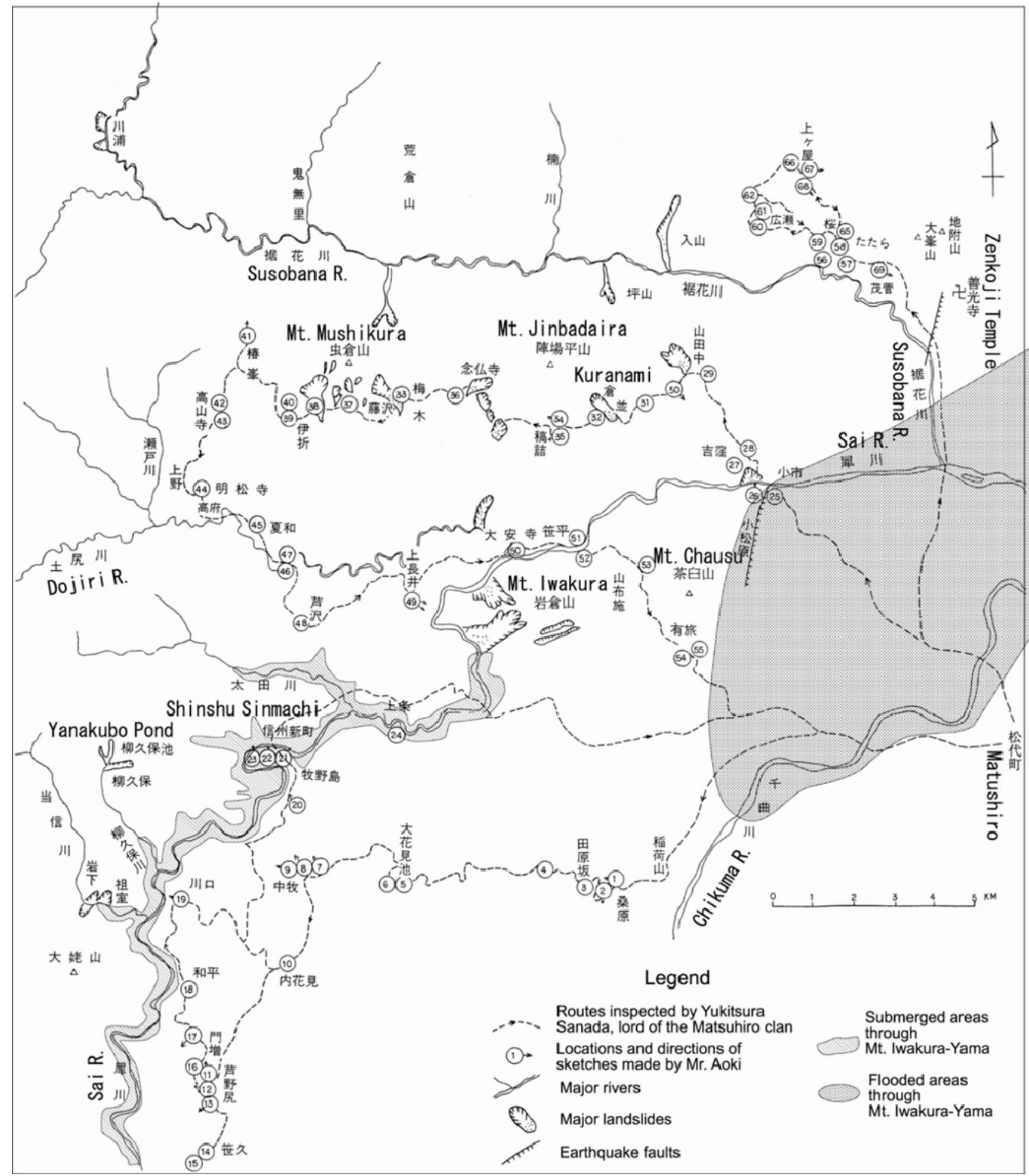

Fig.9 Mt. Iwakura landslide dam, outburst flood area and sketch point of painter Sekkei Aoki (Zenkoji Earthquake Disaster Study Group, 1994, Inoue et al., 2008)

Chuetsu (Mid-Niigata) Earthquake on 24 October, 2004. Figure 9 shows the Mt. Iwakura landslide dam and the outburst flood area. The largest landslide resulting from the Zenkoji Earthquake, with an estimated sediment movementof 20 million $\mathrm{m}^{3}$, occurred at Mt. Iwakura and created a large landslide dam which blocked the midstream section of the Shinano River (the Sai River).

Yukitsura Sanada, lord of the Matsushiro Clan, undertook an inspection tour of his territory two years after the earthquake. Figure 8 shows a sketch from the tour by Sekkei Aoki. The sketch shows Inhabitants of the inspected area prostrate on the ground. Figure 10 shows maps No.3 and No.4 of 


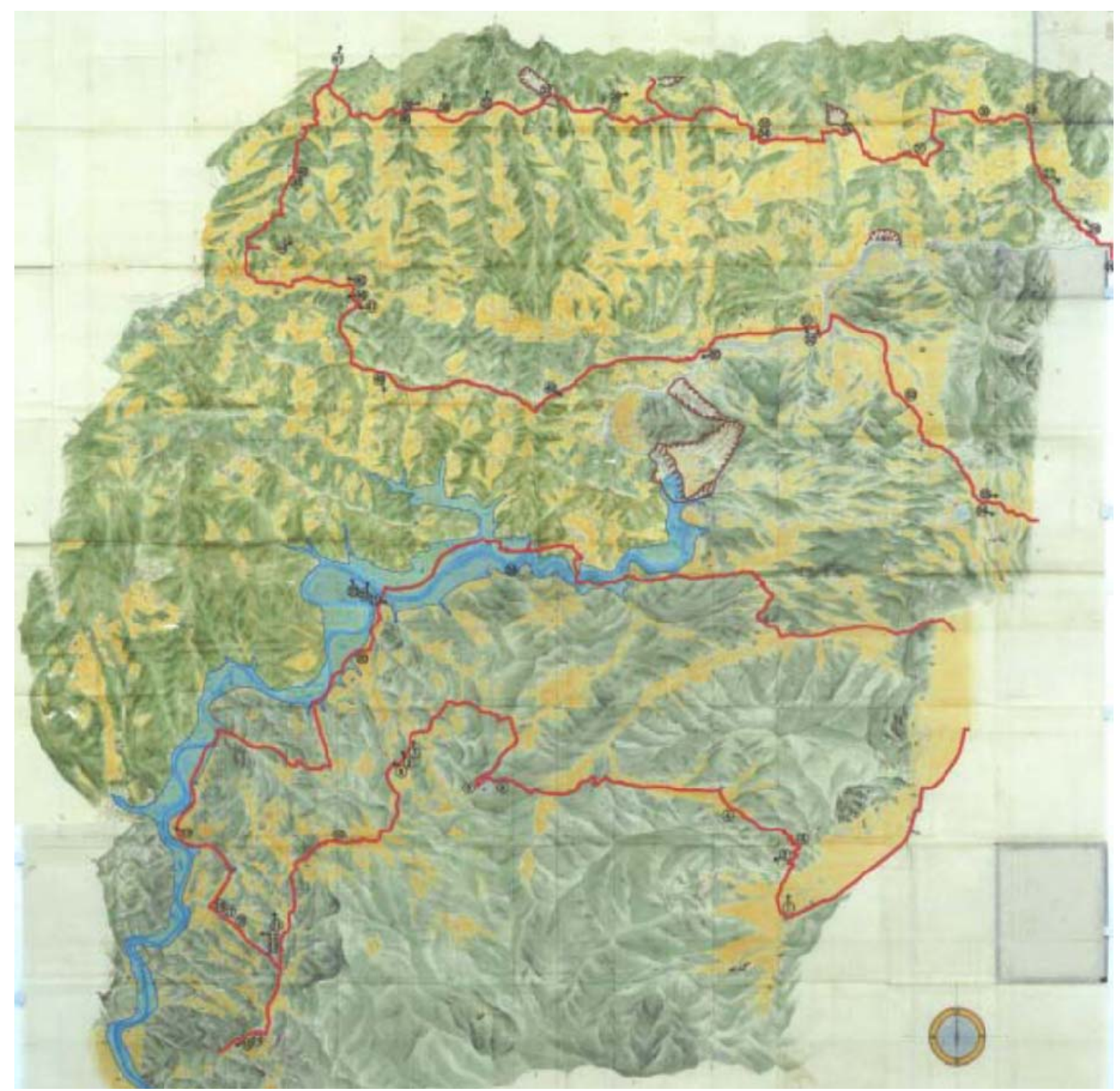

Fig. 10 Maps No.3 and No.4 from the Matsushiro Territory Survey (Kyoto University Museum)

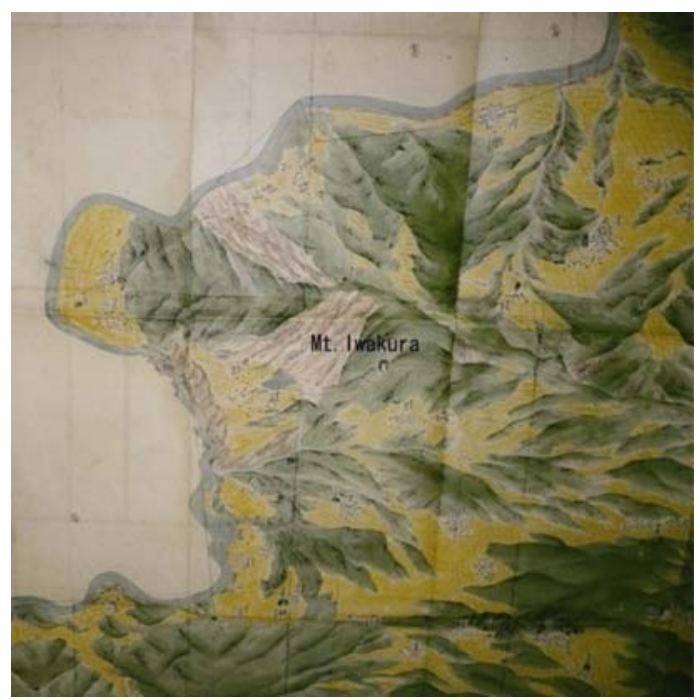

Fig. 11 Mt. Iwakura landslide dam mapped by the Matsushiro Clan in 1852, five years after the earthquake (Kyoto University Museum)

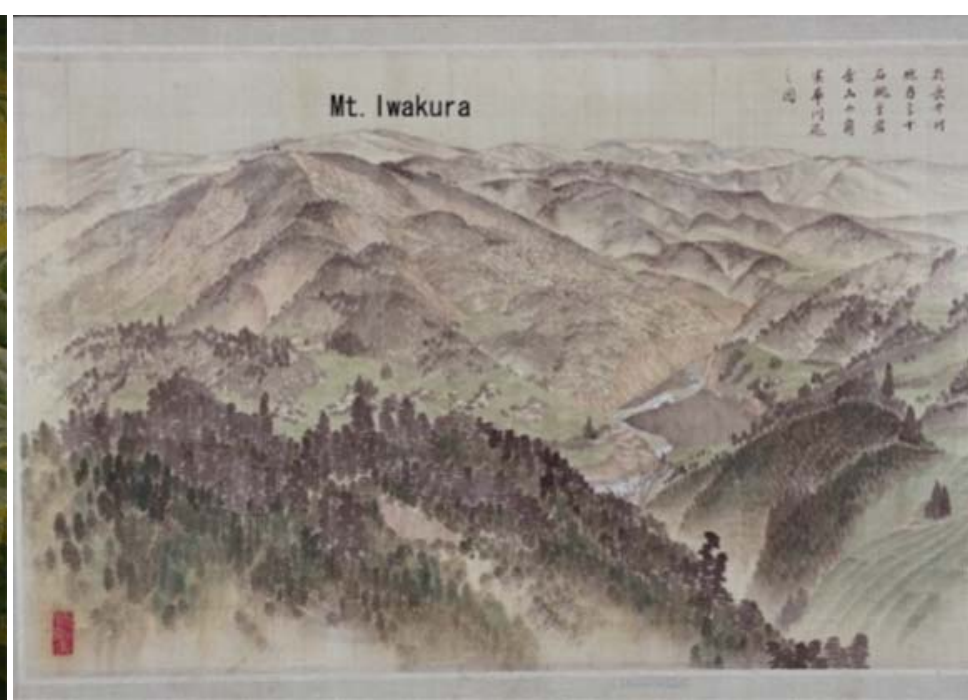

Fig. 12 Mt. Iwakura landslide dam sketched by Sakkei Aoki, (sketch No. 49) in 1849, two years after the earthquake (Sanada Museum in Nagano City) 


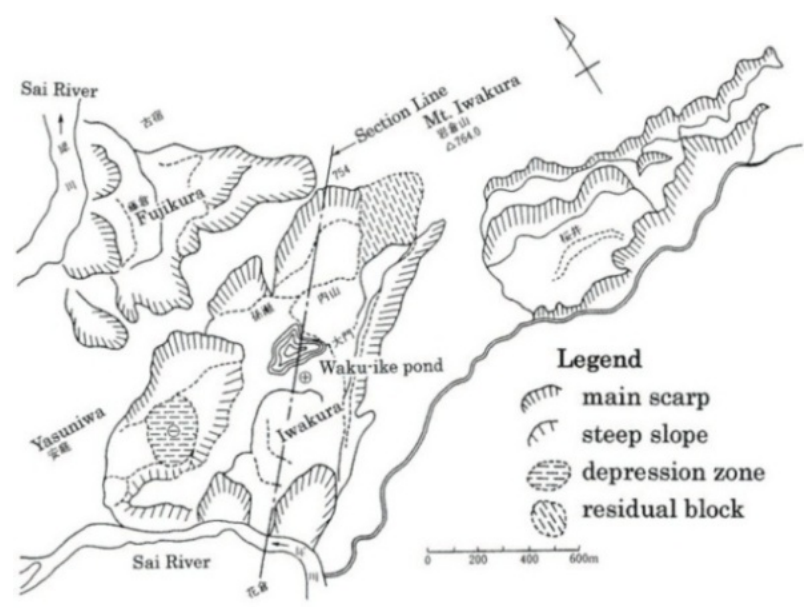

Fig. 13 Topographical map of Iwakura Landslide (Zenkoji Earthquake Disaster Study Group, 1994)

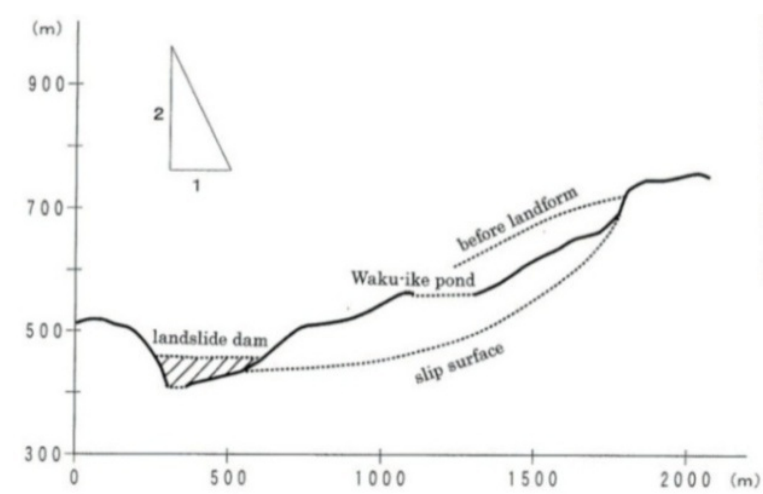

Fig. 14 Longitudinal Section of Iwakura Landslide (Nakamura et al., 2000; Inoue et al., 2008)

the Matsushiro Territory Survey. These maps (eight sheets in all) were drawn five years after the earthquake and are owned by Kyoto University Museum. Red lines on the maps indicated the course of the inspection tour by the party of Yukitsura Sanada. The blue area was submerged by the Iwakura landslide dam. Figure 11 is a close up view of the Mt. Iwakura landslide dam area in map No.4 of the Matsushiro Territory Survey.

Sekkei Aoki also sketched the Mt. Iwakura landslide, in 1849 two years after the earthquake, as shown in sketch No.49 in Figure 12. Figure 13 presents a topographical map of the Mt. Iwakura landslide [Zenkoji Earthquake Disaster Study Group, 1994], Figure 14 shows a longitudinal section of the Iwakura landslide [Nakamura et al., 2000; Inoue et al., 2008]. Although the river blockage was only $65 \mathrm{~m}$ high, the water volume reached as much as $350 \mathrm{~m}^{3}$. The water level reached its maximum 16 days after the landslide, fed by abundant water supply from melted snow (the average flow rate was $254 \mathrm{~m}^{3} / \mathrm{s}$ ). The water gradually began to overflow from the top of the dam, eroding the 1,000 m-long mass of debris. The landslide dam finally collapsed on the 19th day. The resulting flood reached a height of $21 \mathrm{~m}$ and a peak flow of $34,000 \mathrm{~m}^{3} / \mathrm{s}$, damaging downstream area that are now part of Nagano Prefecture.

\section{AFTERWORD}

We have detailed the formation and bursting of three historical landslide dams and the resulting flooding using information from maps and drawings. Historical records of landslide dams and their associated floods will be further studied and documented.

We are currently simulating the bursting phenomena of landslide dams and studying risk management in relation to these phenomena. This information will be useful for disaster prevention planning and for creating early warning and evacuation systems.

\section{References}

Azumi Museum of Matsumoto City (2006): Landslide in Tobata and flood disaster by outburst of landslide dam in the Edo period, p. 58 (in Japanese).

Geological Survey of Japan (1995): Strip Map of the Itoigawa-Shizuoka Tectonic Line Active Fault System, 1:100,000 (in Japanese with English abstract).

Inoue K. (2010): Debris flows and flood-induced disasters caused by the eruption on Asama Volcano in 1783 and restoration projects thereafter, Interpaevent 2010, International Symposium in Pacific Rim, Taipei/Taiwan, pp. 197-205.

Inoue K. (2012): Landslide dam disasters in Kii Peninsula in 1889. Sabo, 45(1), pp. 56-61 (in Japanese)

Inoue K., Kawasaki T. and Machida T. (2010): Otuki River debris avalanche on Yatsugatake, - Research of the gigantic debris avalanche and outburst flooding of the largest landslide dam in 887. Geography, 55(5), pp. 106-116 (in Japanese).

Inoue K., Mizuyama T., and Sakatani Y.(2010): The catastrophic Tombi landslide and accompanying landslide dams induced by the 1858 Hietsu Earthquake. Journal of Disaster Research, 5(3), pp. 245-256.

Inoue K., Mori T. \&Mizuyama T. (2008): Two large landslide dams and outburst disasters in the Shinano River, Central Japan, Intepraevent 2008 Dornbirn/Austria, Session V, pp. $121-129$.

Inoue K., Mori T. and Mizuyama T. (2012): The formation and outburst flood of the largest landslide dam on the Yatsugatake Volcano in Japan. 12th Congress Interpraevent 2012 Grenoble/France, Poster A19, Extended Abstracts, pp. 276-277.

Kawachi S. (1983): Ohtsukigawa debris avalanche, Yatsugatake Volcanic Chain, central Japan. Journal of Geography, 89(3), pp. 173-182 (in Japanese with English abstract).

Kawasaki T. (2010): The sector collapse of Yatsugatake Volcano in 887 and the large floods of Chikuma River in 888. 
Saku, 60, pp. 2-12.(in Japanese).

Machida T., Inoue K., Shimada K. and Tamura T. (2009): Extent and volume of the landslide-dam outbreak flood deposits in A.D. 887 along the upper Chikumagawa: estimated from evidence on the lower river terrace, J.G.U. Meeting in October 2009 (in Japanese).

Mizuyama T., Mori T., Sakaguchi T. and Inoue K. (2011): Landslide dams and countermeasure method in Japan, Kokon Shoin, p. 205 (in Japanese).

Mizuyama T., Tabata S., Mori T., Watanabe F. and Inoue K. (2004): Outburst of Landslides Dams and Their Prevention, Interpraevent 2004-Riva/Trient, Session IV, pp. 221-229.

Mori T., Inoue K., Mizuyama T. and Ueno T. (2007): The Tobata landslide dam and outburst floods in the Azusa River in 1757, Journal of the Japan Society of Erosion Control Engineering, 60(3), pp. 25-30 (in Japanese with English abstract).
Nakamura H., Tsuchiya T., Inoue K. \& Ishikawa Y. (2000): Earthquake Sabo, Kokon Shoin, p. 190 (in Japanese).

Otsuka T. and Nemoto J. (2003): The landslide dam at Tobata (1757) along the Azusa River, Azumi Village, Nagano Prefecture, central Japan, The Annals of Environmental Science, Shinshu University, 25, pp. 81-89 (in Japanese).

Schuster, R., L. (1986): Landslide Dams: Risk and Mitigation, Geotechnical Special Publication No.3, American Society of Civil Engineers, p. 163.

Tabata S., Mizuyama T. and Inoue K. (2002): Landslide Dams and Disasters, Kokon Shoin, p. 205 (in Japanese).

Zenkoji Earthquake Disaster Study Group (1994): Zenkoji Earthquake and landslide disaster, p. 130 (in Japanese).

Received: 14 July, 2009

Accepted: 16 August, 2012 